\title{
Article
}

\section{ICT, Financial Sector Development and Financial Access}

Asongu, Simplice and Nwachukwu, Jacinta Chikaodi

Available at http://clok.uclan.ac.uk/25158/

Asongu, Simplice and Nwachukwu, Jacinta Chikaodi ORCID: 0000-0003-29879242 (2017) ICT, Financial Sector Development and Financial Access. Journal of The Knowledge Economy . pp. 1-26. ISSN 1868-7865

It is advisable to refer to the publisher's version if you intend to cite from the work. http://dx.doi.org/10.1007/s13132-017-0477-x

For more information about UCLan's research in this area go to http://www.uclan.ac.uk/researchgroups/ and search for < name of research Group>.

For information about Research generally at UCLan please go to http://www.uclan.ac.uk/research/

All outputs in CLoK are protected by Intellectual Property Rights law, including Copyright law. Copyright, IPR and Moral Rights for the works on this site are retained by the individual authors and/or other copyright owners. Terms and conditions for use of this material are defined in the policies page.

\section{CLoK}

Central Lancashire online Knowledge www.clok.uclan.ac.uk

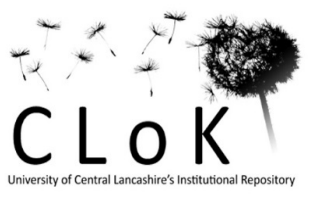




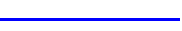


ICT, Financial Sector Development and Financial Access

\author{
Simplice A. Asongu \\ African Governance and Development Institute, \\ P.O. Box 8413, Yaoundé, Cameroon \\ E-mail: asongusimplice@yahoo.com \\ Jacinta C. Nwachukwu \\ School of Economics, Finance and Accounting, \\ Faculty of Business and Law, \\ Coventry University Priory Street, Coventry, CV1 5FB, UK \\ Email: jacinta.nwachukwu@ coventry.ac.uk
}




\title{
ICT, Financial Sector Development and Financial Access
}

\begin{abstract}
This study assesses the role of ICT (internet and mobile phone penetration) in complementing financial sector development (financial formalization and informalization) for financial access. The empirical evidence is based on Generalised Method of Moments with 53 African countries for the period 2004-2011. The following findings are established from linkages between ICT, financial sector development and financial activity. First, the interaction between ICT and financial formalization (informalization) decreases (increases) financial activity. Second, with regards to net effects, the expected signs are established for the most part. In spite of the negative marginal effects from financial informalization, the overall net effects are positive. Third, the potentially appealing interaction between ICT and informalization produces positive thresholds that are within ranges. Policy implications are discussed in three main strands. They include implications for (i) mobile/internet banking; (ii) a quiet life and (iii) ICT in reducing information asymmetry and surplus liquidity.
\end{abstract}

JEL Classification: G20; G29; L96; O40; O55

Keywords: Allocation efficiency; Financial sector development; ICT

\section{Compliance with Ethical Standards}

The authors are self-funded and have received no funding for this manuscript. The authors also have no conflict of interest.

This article does not contain any studies with human participants or animals as performed by the author.

\section{Acknowledgement}

The authors are indebted to the editor and referees for constructive comments. 


\section{Introduction}

Positioning of an inquiry on linkages between information and communication technology (ICT), financial sector development and financial access in Africa has a fourfold motivation, namely: (i) the scope of ICT on that continent, (ii) need for alternative sources of finance for Africa's growing investment needs, (iii) rising concerns about surplus liquidity and gaps in the measurement of financial development and (iv) scarce literature on financial sector development.

First, there is considerable scope for the development of ICT in Africa compared to other regions of the world. As documented in recent ICT literature (Penard et al., 2012; Asongu, 2015a), the continent is experiencing an uneven development in mobile phone and internet penetration. According to the narrative, whereas as of 2010 mobile phone and internet penetrations had reached saturation levels in developed economies, their development in Africa was low and asymmetric with 41 percent (9.6 percent) of mobile phone penetration (internet penetration). The studies are consistent with the view that the ICT market in Africa represents considerable opportunities for doing business because high-end markets in Asia, North America and Europe are experiencing stabilization in the penetration of the mobile phone and internet.

Second, the African business literature accords with the view that domestic sources of capital are needed to finance Africa's growing investment ambitions (Rolfe \& Woodward, 2004; Bartels et al., 2009; Tuomi, 2011; Darley, 2012). A means of internal finance is through the role of financial intermediaries in the transformation of mobilized domestic deposits into credit.

Third, unfortunately the need for internal finance on the continent starkly contrasts with substantially documented concerns of surplus liquidity in the financial intermediary sector (Saxegaard, 2006; Fouda, 2009; Asongu, 2014a). Furthermore, the literature has failed to assess this anxiety in the light of conceiving and measuring financial development efficiency as to the ability of financial institutions to fulfil their fundamental role of transforming mobilized deposits into credit. (see Ataullah et al. 2004; Al-Obaidan, 2008; Kiyato, 2009; Kablan, 2010). The financial efficiency indicators employed in the African financial development literature have included: profit efficiency (Hauner \& Peiris, 2005); Data Envelopment Analysis (DEA) for technical efficiency (Kablan, 2009) and cost efficiency (Chen, 2009; Mensah et al., 2012).

Fourth, financial sector development has not been given the attention it deserves in the finance literature. In accordance with recent papers (O'Toole, 2014; Asongu, 2015b), the bulk 
of studies has been restricted to more specific dimensions of financial institutions like foreign bank participation and bank concentration. We deviate from this by focusing on financial sector development in terms of competition. Theoretically, whereas a considerable proportion of the literature has assessed the effect of financial reforms on financial development (Arestis et al., 2002; Batuo \& Kupukile, 2010), this study argues that the failure to introduce the concept of financial sector development through shares of formal and informal financial sectors is a substantial missing link in the literature.

Noticeably, the above literature leaves room for improvement in three main areas. They involve he need to: (i) focus on regions where concerns about financial access are most severe; (ii) understand financial development from the perspective of the fundamental role of banks in transforming mobilized deposits into credit in the light of substantially documented surplus liquidity issues and (iii) examine the role of ICT in financial sector development for financial access.

By introducing the concept of financial sector development (which is discussed in detail in Section 2), this study unites two streams of research by simultaneously contributing to the macroeconomic literature on measuring financial development and responding to the growing field of economic development by means of informal finance and ICT. Moreover, the empirical exercise suggests a pragmatic way of disentangling the effect of various financial sectors on financial development. In essence, we introduce hitherto unexplored concepts of financial sector formalization and informalization.

In the light of the above, this study further examines the role of ICT in financial sector development (or financial sector competition) for financial access in 53 African countries for the period 2004-2011. The rest of the paper is structured as follows. Section 2 discusses theoretical underpinnings and clarifies the concept of financial sector development. Data and methodology are covered in Section 3. The empirical results and policy implications are presented in Section 4. Section 5 concludes and advises on future research directions.

\section{Theoretical Underpinnings and Financial Sector Development}

This section is discussed in three principal strands: (i) the first-two engage the nexus between information sharing and financial allocation efficiency on the one hand and the intuition motivating the relevance of ICT in information sharing for financial access on the other, and (ii) the last-strand clarifies the concept of financial sector development within the framework of financial sector competition. 
First, consistent with Claus and Grimes (2003), there are two dominant thoughts in the literature on the theoretical relationship between financial development and the sharing of information. The earliest is concerned with the transformation of risk characteristics of bank assets whereas the next focuses on channels through which the provision of liquidity by banks can be consolidated. Furthermore, both strands accord with the fact that the fundamental role of financial intermediation is to consolidate financial allocation efficiency through cost reduction and the optimal funnelling of financial resources from lenders to borrowers.

Second, ICT has been established in developing countries to diffuse information between market participants. Some of the appeals of ICT facilitating financial access include (i) reducing the cost of marketing and enhancing participation in the market (Muto \& Yamano, 2009, p. 1887) and (ii) decreasing information asymmetry (Aminuzzaman et al., 2003). In a nutshell, the intuition underlying ICT in financial sector competition for financial development builds on the fact that ICT has been documented to reduce information asymmetry (Andonova, 2006) and boost competition between formal and informal financial sectors (Asongu, 2013).

In the light of the above, the relevant question underlying the theoretical underpinning is the following: how can ICT help in the development of one financial sector vis-à-vis another in view of improving financial access? The foundations are based on the intuition that the ICT increases banking sector competition for financial access. This perception is consistent with the internet growth and economic growth theory by Goel and Hsieh (2002): "We argue that some effects of the Internet can be understood within the context of traditional economics. Specifically, the Internet has the potential to make market more contestable and hence more competitive," (p. 221). In what follows, we first discuss the relationship between ICT and financial access and then the relevance of ICT-driven financial sector development for financial access.

On the importance of ICT in financial access, ICT is relevant in enabling financial institutions to increase the availability of credit to corporations and households. Therefore, ICT through information sharing contributes to reducing information asymmetry and therefore enhances the capacity of financial institutions to assess the risk profiles of borrowers. Hence, ICT enables banks and credit agencies to share information on borrower risk profiles. When such data on credit history is provided to financial institutions by means of ICT, banks use this information to reduce their adverse selection because they can more exhaustively examine the collateral of borrowers with information provided by sharing 
offices. This process ultimately decreases financial access constraints in households as well as small, micro and medium enterprises (Asongu et al., 2016).

On the relevance of ICT-driven financial sector development for financial access, two perspectives are worth mentioning. On the one hand, the formal financial sector which is more organised than the informal financial sector, can more effectively put in place ICT systems that would increase the amount of the monetary base circulating through the formal financial sector. This is the case with developed countries whereby means of ICT, almost the entire monetary base of their economies circulates within the formal financial sector. On the other hand, from an indirect perspective, information sharing offices (ex-post of the borrowing process) also play a role in market discipline by cautioning borrowers on the unhealthy consequences of non-compliance with their financial obligations in the hope that relying on the informal financial sector may be a viable alternative. Such discipline is facilitated by the ICT channels which information sharing offices naturally employ.

Third, Asongu (2014b) has built on shortcomings in the literature on measuring financial development to address the neglect of the informal financial sector by the International Monetary Fund (IMF)'s International Financial Statistics (IFS) definition of the financial system which does not incorporate the informal financial sector. According to the authors, the literature has either subtracted currency circulating outside the formal financial sector in the measurement of liquid liabilities and/or employed principal component analysis to attenuate concerns about the superiority of financial development indicators. Moreover, there is a common acknowledgement of the neglect of the informal financial sector in the measurement of financial development. Unfortunately, the underlying neglect of the informal financial sector has not been addressed because none of the stream of solutions has incorporated the informal financial sector into the measurement of financial development.

Table 1 summarizes propositions that incorporate the informal financial sector in the definition of the financial system. These propositions are increasingly being employed in the economic development literature (see Asongu, 2015bc). While Panel A presents financial sector measures based on Gross Domestic Product (GDP), the indicators in Panel B are related to financial sector competition. The notion of financial sector development builds on concepts of formalization, semi-formalization, informalization and non-formalization. For instance, financial formalization is the development of the formal financial sector to the detriment of the non-formal financial sector while financial informalization is the development of the informal financial sector to the detriment of the formal and semi-formal financial sectors. Hence, financial sector development within the framework of financial 
sector competition is the improvement of shares in one financial sector to the detriment of competing financial sectors. In other words, the concept appreciates improvement of financial sectors' shares in terms of money supply.

Table 1: Summary of propositions

\begin{tabular}{|c|c|c|c|}
\hline \multicolumn{4}{|c|}{ Panel A: GDP-based financial development indicators } \\
\hline Propositions & Name(s) & Formula & Elucidation \\
\hline Proposition 1 & $\begin{array}{l}\text { Formal financial } \\
\text { development }\end{array}$ & Bank deposits/GDP & $\begin{array}{l}\text { Bank deposits }{ }^{1} \text { here refer to demand, time } \\
\text { and saving deposits in deposit money } \\
\text { banks. }\end{array}$ \\
\hline Proposition 2 & $\begin{array}{l}\text { Semi-formal } \\
\text { financial } \\
\text { development }\end{array}$ & $\begin{array}{l}\text { (Financial deposits - } \\
\text { Bank deposits)/ GDP }\end{array}$ & $\begin{array}{l}\text { Financial deposits }{ }^{2} \text { are demand, time and } \\
\text { saving deposits in deposit money banks } \\
\text { and other financial institutions. }\end{array}$ \\
\hline Proposition 3 & Informal financial & (Money Supply - & \\
\hline & development & Financial deposits)/GDP & \\
\hline Proposition 4 & $\begin{array}{l}\text { Informal and semi- } \\
\text { formal financial } \\
\text { development }\end{array}$ & $\begin{array}{l}\text { (Money Supply - Bank } \\
\text { deposits)/GDP }\end{array}$ & \\
\hline \multicolumn{4}{|c|}{ Panel B: Measures of financial sector importance } \\
\hline Proposition 5 & $\begin{array}{l}\text { Financial } \\
\text { intermediary } \\
\text { formalization }\end{array}$ & $\begin{array}{l}\text { Bank deposits/ Money } \\
\text { Supply (M2) }\end{array}$ & $\begin{array}{l}\text { From 'informal and semi-formal' to formal } \\
\text { financial development (formalization) }{ }^{3} \text {. }\end{array}$ \\
\hline Proposition 6 & $\begin{array}{l}\text { Financial } \\
\text { intermediary 'semi- } \\
\text { formalization' }\end{array}$ & $\begin{array}{l}\text { (Financial deposits - } \\
\text { Bank deposits)/ Money } \\
\text { Supply }\end{array}$ & $\begin{array}{l}\text { From 'informal and formal' to semi-formal } \\
\text { financial development (Semi- } \\
\text { formalization) }{ }^{4} \text {. }\end{array}$ \\
\hline Proposition 7 & $\begin{array}{l}\text { Financial } \\
\text { intermediary } \\
\text { 'informalization' }\end{array}$ & $\begin{array}{l}\text { (Money Supply - } \\
\text { Financial deposits)/ } \\
\text { Money Supply }\end{array}$ & $\begin{array}{l}\text { From 'formal and semi-formal' to informal } \\
\text { financial development (Informalisation) }{ }^{5} \text {. }\end{array}$ \\
\hline Proposition 8 & $\begin{array}{l}\text { Financial } \\
\text { intermediary 'semi- } \\
\text { formalization and } \\
\text { informalization' }\end{array}$ & $\begin{array}{l}\text { (Money Supply - Bank } \\
\text { Deposits)/Money Supply }\end{array}$ & $\begin{array}{l}\text { Formal to 'informal and semi-formal' } \\
\text { financial development: (Semi- } \\
\text { formalization and informalization) }{ }^{6}\end{array}$ \\
\hline
\end{tabular}

N.B: Propositions 5, 6, 7 add up to unity (one); arithmetically spelling-out the underlying assumption of sector importance. Hence, when their time series properties are considered in empirical analysis, the evolution of one sector is to the detriment of other sectors and vice-versa.

Source: Asongu (2015b).

In the light of the literature which has documented the neglect of the informal financial sector (Aryeetey, 2005; Adeusi et al., 2012; Meagher, 2013; Tchamyou \& Asongu, 2017), the

\footnotetext{
${ }^{1}$ Lines 24 and 25 of the International Financial Statistics (October 2008).

${ }^{2}$ Lines 24, 25 and 45 of the International Financial Statistics (2008).

3 "Accordingly, in undeveloped countries money supply is not equal to liquid liabilities or bank deposits. While in undeveloped countries bank deposits as a ratio of money supply is less than one, in developed countries this ratio is almost equal to 1. This indicator appreciates the degree by which money in circulation is absorbed by the banking system. Here we define 'financial formalization' as the propensity of the formal banking system to absorb money in circulation" (Asongu, 2015b, p. 432).

4 "This indicator measures the rate at which the semi-formal financial sector is evolving at the expense of formal and informal sectors" (Asongu, 2015b, p. 432).

5 "This proposition appreciates the degree by which the informal financial sector is developing to the detriment of formal and semi-formal sectors" (Asongu, 2015b, p. 432).

6 "The proposition measures the deterioration of the formal banking sector in the interest of other financial sectors (informal and semi-formal). From common sense, propositions 5 and 8 should be almost perfectly antagonistic, meaning the former (formal financial development at the cost of other financial sectors) and the latter (formal sector deterioration) should almost display a perfectly negative degree of substitution or correlation" (Asongu, 2015b, p. 432).
} 
propositions challenge existing views in four main areas, notably: (i) with a definition of the financial system that incorporates the informal financial sector; (ii) disentanglement of the existing financial system definition into its formal and semi formal components; (ii) incorporation of the previously missing informal financial sector and (iv) introduction of the notion of financial sector development within the framework of financial sector competition.

\section{Data and Methodology}

\subsection{Data}

The study examines a panel of 53 African nations with data from the Financial Development and Structure Database (FDSD) and African Development Indicators (ADI) of the World Bank for the period 2004-2011. While the focus on African countries is consistent with stylized facts on surplus liquidity concerns in the Introductory section, the motivation for the choice of the periodicity is twofold. On the one hand, it coincides with the dates during which information sharing offices (public credit registries and private credit bureaus) were established across the continent to enhance information sharing. On the other, it is consistent with the choice of the empirical strategy. In principle, the adoption of the Generalised Method of Moments (GMM) requires that (i) Time (T) is less than the Number of crosssections $(\mathrm{N})$ and (ii) a higher order of $\mathrm{T}$ leads to instrument proliferation that invalidate estimated output.

In accordance with the motivation in the introduction (see Penard et al., 2012; Tchamyou, 2016; Asongu, 2015a), ICT is measured with internet and mobile phone penetration rates. Two sets of indicators that are consistent with the policy syndrome of surplus liquidity in financial institutions are employed. First, financial activity or credit availability is measured with: (i) banking system activity (with 'private domestic credit by deposit banks') and (ii) financial system activity (with 'private domestic credit by deposit banks and other financial institutions'). Second, financial allocation efficiency which assesses the ability to transform mobilised deposits into credit is measured with (i) banking-systemefficiency (with 'banking system credit' on 'banking system deposits') and (ii) financialsystem-efficiency (with 'financial system credit' on 'financial system deposits'). Two financial sector competition indicators are employed, namely: Proposition 5 (or financial sector formalization) and Proposition 7 (or financial sector informalization). While Proposition 6 (or financial sector semi-formalization) is not used because of constraints in degrees of freedom, Proposition 8 (or financial sector non-formalization) displays a substantial degree of substitution with Proposition 7. 
In order to account for bias from variable omission, six control variables that are consistent with recent financial development literature are used, namely: the lagged dependent variable; inflation, GDP growth, trade, public investment and foreign aid (Huang, 2005; Osabuohein \& Efobi, 2013; Asongu, 2014c). From a preliminary examination, accounting for more than six control indicators results in instrument proliferation, such that the number of cross sections is lower than the number of instruments in post-estimation diagnostics. We discuss expected signs.

Trade openness has been documented to positively influence financial development (see Do \& Levchenko, 2004; Huang \& Temple, 2005). Huang (2011) has established a positive connection between financial development and investment. Both empirical (Boyd et al., 2001) and theoretical (Huybens \& Smith, 1999) literature are consistent with the perspective that countries with chaotic inflation are associated with less efficient, smaller and less active banks. The positive relationship between growth and financial development has been well established in the literature (Greenwood \& Jovanovic, 1992; Saint-Paul, 1992; Levine, 1997; Jaffee \& Levonian 2001). According to the narrative, economic prosperity is associated with more financial intermediation because of, among others, the availability of more funds for productive investments and enhanced competition. Foreign aid is expected to improve financial development because it is anticipated to reduce the saving- or financeinvestment gap that poor countries are confronted with (Easterly, 2005). However, from a practical view point, these effects could also be negative if development assistance is not spent in recipient countries for several reasons, inter alia: foreign aid is siphoned off by a corrupt elite and recycled in tax havens based in developed countries and/or a considerable bulk of the disbursed funds are spent in donor countries.

Appendix 1 and Appendix 2 disclose the definition of variables and summary statistics respectively while the correlation matrix is provided in Appendix 3. We observe from the summary statistics that the variables are comparable by virtue of their means. Moreover, from the corresponding standard deviations, we can be confident that reasonable estimated linkages could be derived. The correlation matrix helps the study to avoid concerns of multicollinearity. After a preliminary examination, concerns about multicollinearity are apparent between financial sector competition, financial development and ICT variables. Whereas this concern is not of major significance in the financial development indicators because they are used exclusively as dependent variables, the ICT and financial sector competition variables are employed in distinct specifications. 


\subsection{Methodology}

\subsubsection{Specification}

The empirical strategy adopted by this study is the GMM with forward orthogonal deviations as opposed to differencing. This empirical strategy is an extension by Roodman (2009ab) of Arellano and Bover (1995). As documented by Love and Zicchino (2006) and Baltagi (2008), this empirical strategy controls for cross-sectional dependence and limits the proliferation of instruments. The two basic conditions for goodness of fit in GMM are satisfied because: (i) there is persistence in the dependent variables since the correlation between the financial dependent variables and their corresponding first lags is higher than the threshold of 0.800 (see Appendix 4). (ii) the number of cross-sections ( $\mathrm{N}=53)$ is higher than the number of time series $(\mathrm{T}=8)$ in the cross-sections.

The following equations in levels (1) and first difference (2) summarize the estimation procedure.

$$
\begin{gathered}
F D_{i, t}=\sigma_{0}+\sigma_{1} F D_{i, t-\tau}+\sigma_{2} \text { Fin }_{i, t}+\sigma_{3} \text { ICT }_{i, t}+\sigma_{4} \text { Inter }_{i, t}+\sum_{h=1}^{5} \delta_{h} W_{h, i, t-\tau}+\eta_{i}+\xi_{t}+\varepsilon_{i, t} \\
F D_{i, t}-F D_{i, t-\tau}=\sigma_{0}+\sigma_{1}\left(F D_{i, t-\tau}-F D_{i, t-2 \tau}\right)+\sigma_{2}\left(\text { Fin }_{i, t}-F i n_{i, t-\tau}\right)+\sigma_{3}\left(I C T_{i, t}-I C T_{i, t-\tau}\right) \\
+\sigma_{4}\left(\text { Inter }_{i, t}-\text { Inter }_{i, t-\tau}\right)+\sum_{h=1}^{5} \delta_{h}\left(W_{h, i, t-\tau}-W_{h, i, t-2 \tau}\right)+\left(\xi_{t}-\xi_{t-\tau}\right)+\varepsilon_{i, t-\tau}
\end{gathered}
$$

Where: $F D_{i, t}$ is the financial development (efficiency and activity) of country $i$ at period $t ; \alpha$ is a constant; $\tau$ represents tau ; Fin, is an indicator of financial sector competition or financial sector development (financial formalization or financial informalization); ICT, information and communication technology (mobile phone or internet); Inter, interaction between Fin and ICT; $W$ is the vector of five control variables (inflation, public investment, GDP growth, trade and foreign aid), $\eta_{i}$ is the country-specific effect, $\xi_{t}$ is the time-specific constant and $\varepsilon_{i, t}$ the error term. A two-step specification is preferred to the one-step procedure because it controls for heteroscedasticity. Moreover, in the specifications all constitutive terms are entered into the specifications as cautioned by Brambor et al. (2006) on the pitfalls of interactive regressions.

\subsubsection{Identification and exclusion restriction}

In accordance with recent literature (Dewan \& Ramaprasad, 2014; Asongu \& Nwachukwu, 2016ab), all independent indicators are considered as predetermined or suspected endogenous variables. Therefore, the gmmstyle is adopted for them. Furthermore, 
only years are considered as exogenous and the approach for treating ivstyle (years) is 'iv(years, eq(diff))' because it is not feasible for the years to become endogenous in firstdifference (see Roodman, 2009b).

The concerns of simultaneity are tackled by employing lagged regressors as instruments for the forward-differenced variables. Accordingly, fixed effects that are capable of affecting the assessed connections are removed with Helmet transformations which are performed in accordance with Love and Zicchino (2006). These transformations encompass forward mean-differencing of variables. Hence instead of subtracting past observations from contemporary ones (see Roodman, 2009b, p. 104), the average of future observations is subtracted from the indicators. The transformation permits orthogonal or parallel conditions between forward-differenced indicators and lagged values. Irrespective of lag numbers, in order to limit the loss of data, the transformations are computed for all observations with the exception of the last for each country. "And because lagged observations do not enter the formula, they are valid as instruments" (Roodman, 2009b, p. 104).

Considering the above, years that are assumed to exhibit a strict exogeneity affect financial sector development exclusively through endogenous explaining indicators. The statistical validity of the exclusion restriction is investigated with the Difference in Hansen Test (DHT) for instrument exogeneity. In essence, the null hypothesis of the test should not be rejected for the instruments (or years) to elucidate financial sector development exclusively via the endogenous explaining variables. Therefore, the DHT is used to examine whether years exhibit strict exogeneity by not elucidating governance beyond the examined channels (or endogenous explaining variables). Consequently, in the section that follows, the findings should confirm the validity of the exclusion restriction if the null hypotheses of DHT corresponding to IV (year, eq(diff)) are not rejected.

\section{Empirical results}

\subsection{Presentation of results}

The empirical analysis is presented in two-steps. We first assess the role of ICT on financial sector development in financial allocation efficiency before investigating the corresponding interaction in financial activity. Four post-estimation diagnostic tests are used to evaluate the validity of models (Asongu \& De Moor, 2016) ${ }^{7}$. Table 2 and Table 3 respectively present findings corresponding to financial efficiency and financial activity.

\footnotetext{
7 "First, the null hypothesis of the second-order Arellano and Bond autocorrelation test (AR(2)) in difference for the absence of autocorrelation in the residuals should not be rejected. Second the Sargan and Hansen
} 
The findings are discussed in three levels, notably in terms of: marginal impacts, net effects and thresholds at which the marginal impacts with ICT change the sign of the unconditional financial sector development effect. In addition, for a threshold of ICT to have an economic significance, it should be within the range of the corresponding minimum to maximum range provided by the summary statistics. For example, in the second specification of Table 2: (i) the marginal impact of the internet on financial formalization for banking system efficiency is -0.563 ; (ii) the corresponding net effect is $3.945([6.822 \times-0.563]+$ $7.786)^{8}$ and (iii) the threshold at which the negative marginal effect changes the unconditional positive effect of financial formalization (7.786) from positive to negative is -13.829 (7.786/0.563). Unfortunately, the negative threshold is not within the internet penetration range (0.031 to 51.00) disclosed by the summary statistics. No valid inference can be derived from Table 2 at the 1 percent significance level because a post-estimation diagnostic test reveal the presence of autocorrelation in the residuals.

The following findings can be established from Table 3 on linkages between ICT financial sector development and financial activity. First, from marginal effects, the interaction between ICT and financial formalization (informalization) decreases (increases) financial activity. Second, with regard to net effects, the expected signs are established for the most part with the exception of the last-two columns from which we expected net negative effects because informalization should interact with ICT to decrease activities of the formal financial sector. Hence, in spite of the negative marginal effects from financial informalization, the overall interaction still has a positive effect. Third, the potentially appealing interaction between ICT and informalization produces positive thresholds that are within the ranges provided by the summary statistics. As expected, all the four thresholds at which the unconditional negative effects of financial informalization on financial activity become positive make economic sense because they are within the suggested ranges. Fourth, the significant control variables display the expected signs. Accordingly, inflation negatively affects financial activity whereas the effects from trade, foreign aid and public investment are positive.

overidentification restrictions (OIR) tests should not be significant because their null hypotheses are the positions that instruments are valid or not correlated with the error terms. In essence, while the Sargan OIR test is not robust but not weakened by instruments, the Hansen OIR is robust but weakened by instruments. In order to restrict identification or limit the proliferation of instruments, we have ensured that instruments are lower than the number of cross-sections in most specifications. Third, the Difference in Hansen Test (DHT) for exogeneity of instruments isalso employed to assess the validity of results from the Hansen OIR test. Fourth, a Fischer test for the joint validity of estimated coefficients is also provided" ( Asongu \& De Moor, 2016, p.9).

${ }^{8} 6.822$ is the mean value of internet penetration. 


\section{Financial Efficiency}

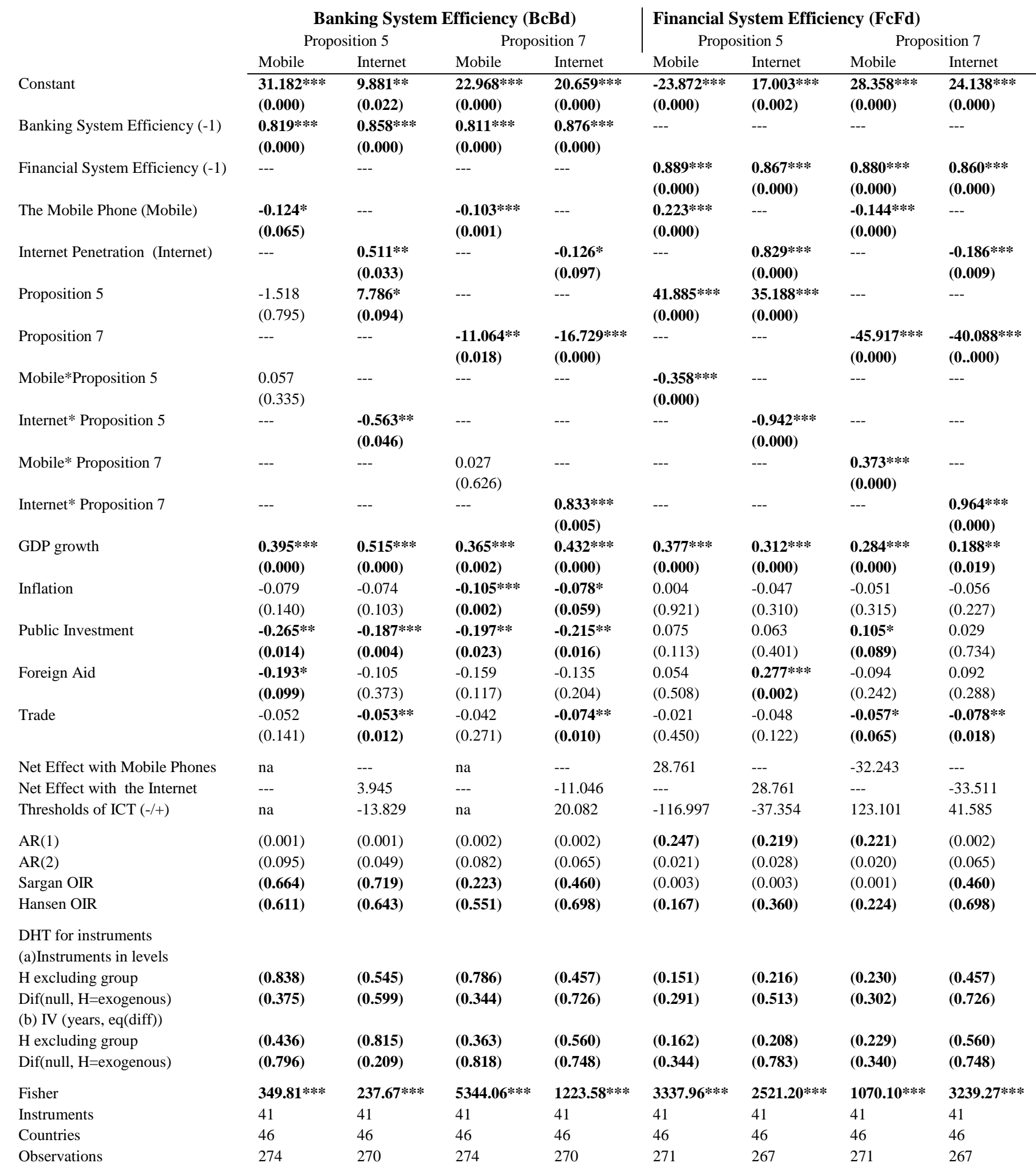

*,**,***: significance levels of 10\%, 5\% and 1\% respectively. DHT: Difference in Hansen Test for Exogeneity of Instruments' Subsets. Dif: Difference. OIR: Over-identifying Restrictions Test. The significance of bold values is twofold. 1) The significance of estimated coefficients, Hausman test and the Fisher statistics. 2) The failure to reject the null hypotheses of: a) no autocorrelation in the AR(1) and AR(2) tests and; b) the validity of the instruments in the Sargan OIR test. GDP: Gross Domestic Product. Proposition 5: Financial Sector Formalization. Proposition 7: Financial Sector Informalization. 


\section{Table 3: Financial Activity, Financial Sector Development and ICT}

\section{Financial Efficiency}

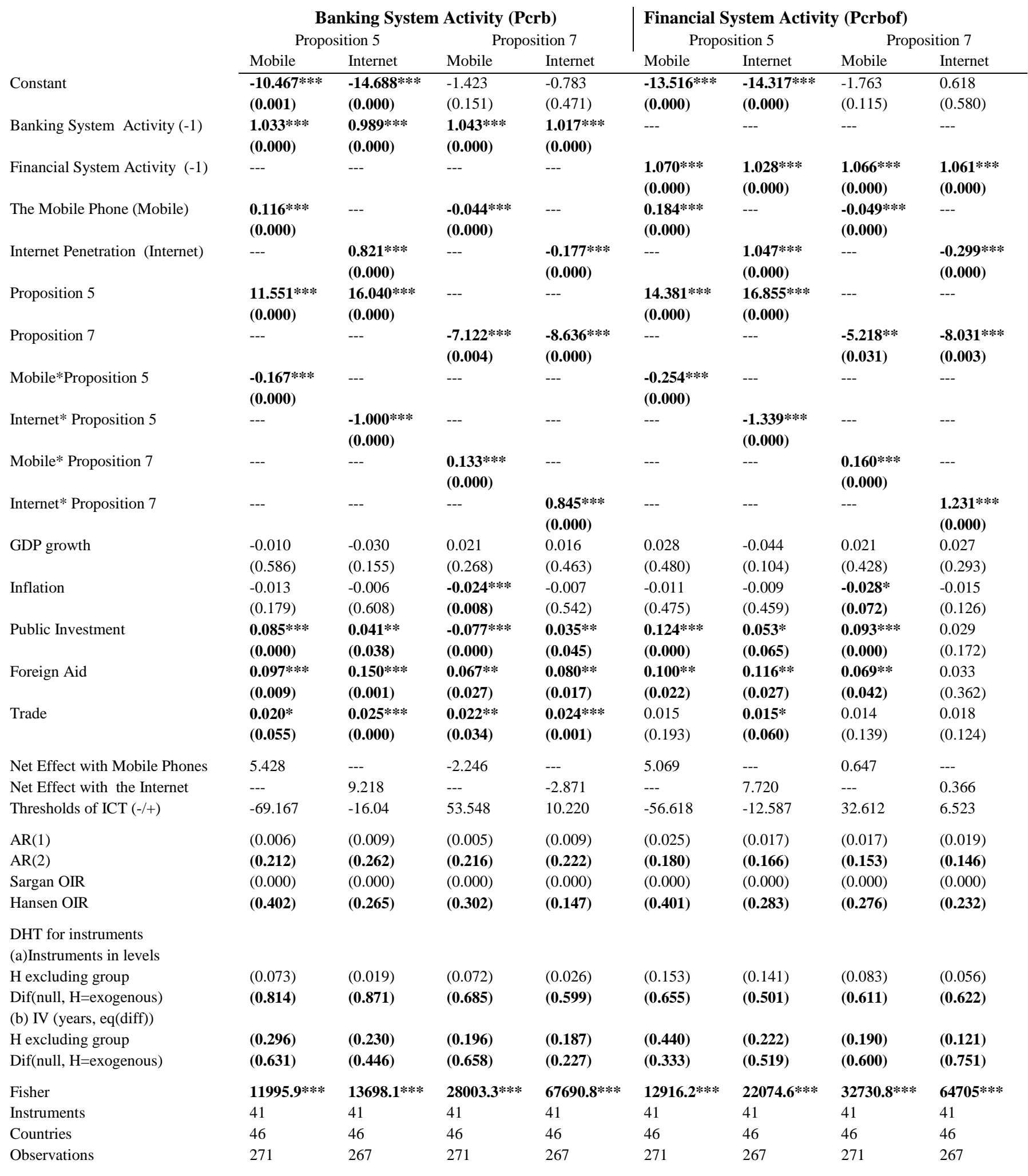

*,**,***: significance levels of 10\%, 5\% and 1\% respectively. DHT: Difference in Hansen Test for Exogeneity of Instruments' Subsets. Dif: Difference. OIR: Over-identifying Restrictions Test. The significance of bold values is twofold. 1) The significance of estimated coefficients, Hausman test and the Fisher statistics. 2) The failure to reject the null hypotheses of: a) no autocorrelation in the AR(1) and AR(2) tests and; b) the validity of the instruments in the Sargan OIR test. GDP: Gross Domestic Product. Proposition 5: Financial Sector Formalization. Proposition 7: Financial Sector Informalization. 


\subsection{Further discussion of results and policy implications}

The findings can be discussed in three main strands, namely: implications for mobile/internet banking; implications for a quiet life and implications for ICT in reducing information asymmetry and surplus liquidity.

\subsection{Implications for mobile/internet banking}

We have established that in spite of the negative marginal impacts from financial informalization, the net effects from the interaction between informalization and ICT on private domestic credit is positive. This is contrary to intuition because mobile phones have been documented to be negatively (positively) correlated with the formal (formal) financial sector of Africa (see Asongu, 2013). Two insights merit emphasis here. On the one hand, the findings of Asongu (2013) are interpreted as correlations because they are based on crosssectional observations for the year 2009. On the other hand, the study does not build on interactions. Whereas the findings of this study enable us to infer causality, there are several explanations to the positive net effects, which we discuss in three main categories:(i) the usefulness of ICT transactions in the store of value, conversion of cash and transfer of stored value, (ii) the concepts of basic and partially integrated savings in ICT banking and (iii) banking in the Global System for ICT. We may deal with each in turn.

First, ICT banking enables users in developing countries to do three main things: (i) It provides users with the possibility of storing value or currency in a mobile phone connected to the internet. Both pseudo bank accounts from the user's mobile operator and real bank accounts from the formal banking sector are used, (ii) ICT enables the conversion of cash into and out of the stored value. Moreover, when conversion is linked to a formal bank account, users can visit banks to cash-out and cash-in. Stored value can be used by banks to boost financial activity or provide credit. (ii) The transfer of stored value between accounts with the help of internet/mobile banking is used by the formal banking sector (e.g. the use of Short Message Service (SMS) for security codes during internet banking).

Second, two types of mobile savings exist (see Demombynes \& Thegeya, 2012). On the one hand, 'basic savings' represent the use of a standard ICT system of mobile transfer such as M-PESA to store money. This option of ICT savings does not an earn interest rate. On the other hand, a 'partially integrated' ICT savings system which earns interest is contingent on the presence of a bank account in a formal banking institution. The interest generated by 
the latter option is based on the savings that are used by banks to increase financial activity (or credit).

Third, a mobile phone connected to the internet with a savings account in a formal banking institution can contribute to increasing financial activity in the following ways: (i) ICT can be used as a store of value because the subscriber identity module (SIM) is similar to a smartcard (or virtual bank card), (ii) ICT can play the role of a point of sale (POS) terminal by enabling transactions and communications with the relevant financial institution (e.g. in the solicitation of transaction authorization) and (iii) ICT can be employed as an automated teller machine (ATM). In the light of the above, the mobile phone with an internet connection enables instant access to bank accounts for transactions.

\subsubsection{Implications for a quiet life}

While the discourse in Section 4.2.1 is linked to the findings in Table 3, it is important to also engage the implications of the results in Table 2 from which valid inferences could not be established because of post-estimation presence of autocorrelation in the residuals. The insignificant findings may be traceable to the fact that, whereas ICT interacts with financial sector development to increase financial activity, it at the same time increases savings in formal banking institutions. These increases in savings or liquid liabilities negatively bear on financial allocation efficiency. It is important to note that financial allocation efficiency (dependent variable in Table 2) is the transformation of liquid liabilities (of financial system deposits) into financial activity (outcome variable in Table 3).

Another possible explanation to the insignificant findings of financial allocation efficiency may be that banks are taking advantage of information sharing and ICT-related mobile/internet banking to enjoy a quiet life. The 'quiet of life hypothesis' (QLH) postulates that banks would take advantage of privileged information and positions to increase their profit margins instead of pursuing their fundamental role of financial allocation efficiency (Coccorese \& Pellecchia, 2010; Coccorese, 2012). Hence, we are tempted to infer that African financial institutions may be taking advantage of ICT and related advantages to improve their margins in profit instead of increasing allocation efficiency. This is essentially because ICT should reduce informational rents associated with the high cost of credit because it diffuses information that potentially mitigates information asymmetry. As a policy implication, information sharing offices (like public credit registries [PCR] and private credit bureaus $[\mathrm{PCB}])$ are essential in complementing information synchronisation from ICT in 
reducing information asymmetry (between lenders and borrowers) for enhanced financial allocation efficiency.

\subsubsection{Implications for ICT of reducing information asymmetry and surplus liquidity}

The implications for ICT in complementing PCB and PCR in reducing information asymmetry for better financial allocation efficiency have twofold aspects. On one hand, ICTs enable these information sharing bureaus (ISB) to increase competition within the financial sector. This point has been articulated in this study by the interaction between ICT and financial sector development (financial sector formalization and informalization). In other words, with the advent of ICT, one financial sector may grow to the detriment of others. Consequently, the money supply shares of one financial sector may increase or decrease as a result of ICT. On the other hand, ICT also acts as a disciplinary device towards borrowers. This is evident from our findings from the perspective that the interaction between ICT and informalization has increasing marginal effects and some overall positive net effects. It implies that with the help of ICT, citizens could still resort to the formal financial sector in spite of financial informalization.

Whereas ICT combined with information sharing bureaus (ISB) can play the role of a disciplinary device by reducing informational rents that might have been previously enjoyed by banks, financial institutions may yet be unwilling to improve financial access if they are not persuaded of a higher repayment probability from borrowers. Hence, ICT and ISB provide performance incentives and reduce moral hazard by penalising borrowers who may be unafraid to lose their reputation and willing to resort to the informal financial sector as a viable alternative to the formal sector. It is within this framework that the net effect of ICT with informalization on private domestic credit is positive.

An implication of fundamental concern is that the relationship between ICT and financial formalization results in negative marginal effects on financial activity. Hence, ICT is a necessary but not a sufficient condition for enhanced allocation of credit. In addition to complementing ICT with ISB to potentially address the issue, the effectiveness of the complementarity would be improved with better synchronisation of information and recruitment of better quality human resources. These can be achieved via inter alia: reliable high-speed access to the internet, regular training of ISB staff and 'knowledge economy'driven economic policies. These ameliorations would contribute to enhancing the battle against the voluntary and involuntary keeping of surplus liquidity in two key ways. First, the discussed ICT and ISB instruments can be tailored to reduce the involuntary holding of 
surplus liquidity through: (i) facilitating contingency-oriented interbank borrowing and mitigation of issues related to transportation that may oblige banks in remote areas to hold surplus cash and (ii) easing bank constraints when it comes to updating their status at central banks in a bid to avoid them from holding reserves above statutory limits. Second, the engaged instruments could also be employed to decrease the involuntary keeping of cash through, among other things: easing bond market investments, improving opportunities so banks are able to invest in regional stock markets, reducing the incapacity of financial institutions to lend in scenarios of regulated interest rates and boosting of lending competition between banks.

\section{Conclusions and further research directions}

This study assesses the role of ICT (internet and mobile phone penetrations) in complementing financial sector development (financial formalization and informalization) for financial access. The empirical evidence is based on Generalised Method of Moments with 53 African countries for the period 2004-2011.The following findings are established from linkages between ICT, financial sector development and financial activity. First, from marginal effects, the interaction between ICT and financial formalization (informalization) decreases (increases) financial activity. Second, with regard to net effects, the expected signs are established for the most part. Hence, in spite of the negative marginal effects from financial informalization, the overall net effects are positive. Third, the potentially appealing interaction between ICT and informalization reveals positive thresholds that are within suggested ranges. These findings are discussed at three primary levels, notably in terms of: (i) marginal impacts, (ii) net effects and (iii) thresholds at which the marginal impacts with ICT change the sign of the unconditional effect of financial sector development. Policy implications are presented in three main strands. These comprise implications for (i) mobile/internet banking; (ii) a quiet life and (iii) ICT in reducing information asymmetry and surplus liquidity.

By introducing the concept of financial sector development, the study has united two streams of research by simultaneously contributing to the macroeconomic literature on measuring financial development and responding to the growing field of economic development by means of informal finance and ICT. Moreover, the empirical exercise has suggested a pragmatic way of disentangling the effect of various financial sectors on financial 
development. Broadly speaking, our study have introduced hitherto unexplored concepts of financial sector formalization and informalization.

Future studies devoted to improving the extant literature can focus on assessing the established linkages throughout the conditional distribution of financial development. This recommendation is based on the fact that blanket policies based on established connections may be more effective if they are contingent on initial levels of financial development and tailored differently across countries with low, intermediate and high levels of financial development.

\section{Appendices}

\section{Appendix 1: Variable Definitions}

\begin{tabular}{|c|c|c|c|}
\hline Variables & Signs & Variable Definitions & Sources \\
\hline Banking System Efficiency & $\mathrm{BcBd}$ & Bank credit on Bank deposits & World Bank (FDSD) \\
\hline Financial System Efficiency & $\mathrm{FcFd}$ & Financial credit on Financial deposits & World Bank (FDSD) \\
\hline Banking System Activity & Prcb & Private domestic credit from deposit banks (\% of GDP) & World Bank (FDSD) \\
\hline Financial System Activity & Prcbof & Private domestic credit from financial institutions (\% of GDP) & World Bank (FDSD) \\
\hline \multirow{2}{*}{$\begin{array}{l}\text { Information and } \\
\text { Communication } \\
\text { Technology }\end{array}$} & Mobile & Mobile phone subscriptions (per 100 people) & World Bank (WDI) \\
\hline & Internet & Internet penetration (per 100 people) & World Bank (WDI) \\
\hline \multirow[t]{2}{*}{ Financial Sector Competition } & Prop. 5 & Financial Sector Formalization & \multirow{2}{*}{$\begin{array}{l}\text { Asongu (2014b, } \\
2015 \mathrm{bc})\end{array}$} \\
\hline & Prop. 7 & Financial Sector Informalization & \\
\hline Economic Prosperity & GDPg & GDP Growth (annual \%) & World Bank (WDI) \\
\hline Inflation & Infl & Consumer Price Index (annual \%) & World Bank (WDI) \\
\hline Public Investment & PubIvt & Gross Public Investment (\% of GDP) & World Bank (WDI) \\
\hline Development Assistance & NODA & Total Net Official Development Assistance (\% of GDP) & World Bank (WDI) \\
\hline Trade openness & Trade & Imports plus Exports in commodities (\% of GDP) & World Bank (WDI) \\
\hline
\end{tabular}

WDI: World Bank Development Indicators. FDSD: Financial Development and Structure Database.

Appendix 2: Summary Statistics (2004-2011)

\begin{tabular}{|c|c|c|c|c|c|c|}
\hline & Variables & Mean & S.D & Min. & Max. & Observations \\
\hline & Financial System Depth (Fdgdp) & 28.262 & 21.066 & 2.926 & 92.325 & 377 \\
\hline Financial & Banking System Efficiency (BcBd) & 68.118 & 27.725 & 14.804 & 171.85 & 402 \\
\hline \multirow[t]{3}{*}{ Access } & Financial System Efficiency (FcFd) & 68.118 & 27.725 & 14.804 & 171.85 & 402 \\
\hline & Banking System Activity (Pcrb) & 72.722 & 35.884 & 22.200 & 252.88 & 377 \\
\hline & Financial System Activity (Pcrbof) & 21.571 & 24.154 & 0.010 & 149.77 & 379 \\
\hline Fin. Sector & Financial Formalization & 0.773 & 0.168 & 0.235 & 1.469 & 377 \\
\hline Competition & Financial Informalization & 0.219 & 0.168 & -0.469 & 0.764 & 377 \\
\hline \multirow[t]{3}{*}{ ICT } & Mobile Phone Penetration & 36.659 & 32.848 & 0.214 & 171.51 & 420 \\
\hline & Internet Penetration & 6.822 & 8.852 & 0.031 & 51.00 & 414 \\
\hline & Economic Prosperity (GDPg) & 4.996 & 4.556 & -17.66 & 37.998 & 404 \\
\hline
\end{tabular}




$\begin{array}{llccccc}\text { Control } & \text { Inflation } & 7.801 & 4.720 & 0 & 43.011 & 357 \\ \text { Variables } & \text { Public Investment } & 74.778 & 1241.70 & -8.974 & 24411 & 387 \\ & \text { Development Assistance } & 10.396 & 12.958 & 0.027 & 147.05 & 411 \\ & \text { Trade Openness (Trade) } & 80.861 & 32.935 & 24.968 & 186.15 & 392 \\ \text { Income } & \text { Low Income Countries } & 0.509 & 0.500 & 0.000 & 1.000 & 424 \\ \text { Levels and } & \text { Middle Income Countries } & 0.490 & 0.500 & 0.000 & 1.000 & 424 \\ \text { Legal } & \text { English Common Law } & 0.415 & 0.493 & 0.000 & 1.000 & 424 \\ \text { Origins } & \text { Civil Law } & 0.584 & 0.493 & 0.000 & 1.000 & 424\end{array}$

S.D: Standard Deviation. Min: Minimum. Max: Maximum. M2: Money Supply. Fdgdp: Financial deposits(liquid liabilities). BcBd: Bank credit on Bank deposits. FcFd: Financial credit on Financial deposits. Pcrb: Private domestic credit from deposit banks. Pcrbof: Private domestic credit from deposit banks and other financial institutions. Dbacba: Deposit bank assets on central bank assets plus deposit bank assets. GDPg: GDP growth.

Appendix 3: Correlation Analysis (Uniform sample size : 291)

\begin{tabular}{|c|c|c|c|c|c|c|c|c|c|c|c|c|c|}
\hline \multicolumn{4}{|c|}{ Financial Access } & \multirow{2}{*}{\multicolumn{2}{|c|}{ Info. Asymmetry }} & \multicolumn{2}{|c|}{ FS Competition } & \multicolumn{5}{|c|}{ Control Variables } & \\
\hline \multicolumn{2}{|c|}{ Fin. Efficiency } & \multicolumn{2}{|c|}{ Fin. Activity } & & & \multirow[b]{2}{*}{ Prop.5 } & & \multirow[b]{2}{*}{ GDPg } & \multirow[b]{2}{*}{ Inflation } & & \multirow[b]{2}{*}{ NODA } & \multirow[b]{2}{*}{ Trade } & \\
\hline $\mathrm{BcBd}$ & $\mathrm{FcFd}$ & Prcb & Pcrbof & Mobile & Internet & & Prop.7 & & & PubIvt & & & \\
\hline \multirow[t]{13}{*}{1.000} & 0.859 & 0.490 & 0.495 & 0.117 & 0.140 & 0.119 & -0.097 & -0.016 & -0.144 & -0.169 & -0.133 & -0.176 & Bcbd \\
\hline & 1.000 & 0.583 & 0.743 & 0.224 & 0.149 & 0.384 & -0.365 & -0.056 & -0.097 & -0.149 & -0.179 & -0.189 & $\mathrm{FcFd}$ \\
\hline & & 1.000 & 0.922 & 0.523 & 0.707 & 0.591 & -0.580 & -0.092 & -0.089 & -0.055 & -0.343 & 0.093 & Pcrb \\
\hline & & & 1.000 & 0.495 & 0.558 & 0.685 & -0.676 & -0.088 & -0.073 & -0.057 & -0.324 & 0.019 & Pcrbof \\
\hline & & & & 1.000 & 0.629 & 0.416 & -0.392 & -0.192 & -0.136 & 0.088 & -0.496 & 0.195 & Mobile \\
\hline & & & & & 1.000 & 0.379 & -0.370 & -0.082 & -0.025 & -0.024 & -0.373 & 0.117 & Internet \\
\hline & & & & & & 1.000 & -0.983 & -0.004 & 0.008 & 0.128 & -0.246 & 0.119 & Prop.5 \\
\hline & & & & & & & 1.000 & 0.018 & -0.061 & -0.125 & 0.224 & -0.105 & Prop.7 \\
\hline & & & & & & & & 1.000 & -0.169 & 0.129 & 0.122 & 0.037 & GDPg \\
\hline & & & & & & & & & 1.000 & -0.081 & -0.0004 & -0.006 & Inflation \\
\hline & & & & & & & & & & 1.000 & 0.059 & 0.130 & PubIvt \\
\hline & & & & & & & & & & & 1.000 & -0.309 & NODA \\
\hline & & & & & & & & & & & & 1.000 & Trade \\
\hline
\end{tabular}

BcBd: Bank credit on bank deposits. FcFd: Financial credit on Financial deposits. Pcrb: Private domestic credit from depositbanks. Pcrbof: Private domestic credit from deposit banks and other financial institutions. Info: Information. Mobile: Mobile phone penetration. Internet: Internet penetration. Prop.5: Financial Sector Formalization. Prop. 7: Financial Sector Informalization. GDPg: GDP growth. Popg: Population growth. PubIvt: Public Investment. NODA: Net Official Development Assistance. Info: Information. FS Competition: Financial Sector Competition.

\section{Appendix 4: Persistence of the dependent variables}

\begin{tabular}{|c|c|c|c|c|c|}
\hline \multirow[b]{3}{*}{$\operatorname{Fdgdp}(-1)$} & \multirow{2}{*}{$\begin{array}{c}\text { Deposits } \\
\text { Fdgdp }\end{array}$} & \multicolumn{2}{|c|}{ Financial Efficiency } & \multicolumn{2}{|c|}{ Financial Activity } \\
\hline & & $\mathrm{BcBd}$ & $\mathrm{FcFd}$ & Pcrd & Pcrdof \\
\hline & 0.990 & & & & \\
\hline $\operatorname{BcBd}(-1)$ & & 0.9438 & & & \\
\hline $\operatorname{FcFd}(-1)$ & & & 0.9815 & & \\
\hline Pcrd (-1) & & & & 0.9919 & \\
\hline Pcrdof(-1) & & & & & 0.9945 \\
\hline
\end{tabular}

\section{References}

Adeusi, S. O., Azeez, B. A., \& Olanrewaju, H. A., (2012). "The Effect of Financial Liberalization on the Performance of Informal Capital Market", Research Journal of Finance and Accounting, 3(6), pp. 1-16. 
Al-Obaidan, A, M., (2008). "Efficiency Effect of Openness in the Banking Industry of Emerging Markets", International Research Journal of Finance and Economics, 17(July), pp. 92-104.

Aminuzzaman, S., Baldersheim, H., \& Jamil, I., (2003). "Talking back! Empowerment and mobile phones in rural Bangladesh: a study of the village phone scheme of Grameen Bank", Contemporary South Asia, 12(3), pp. 327-348.

Andonova, V., (2006). "Mobile phones, the Internet and the institutional environment", Telecommunications Policy, 30(1), pp. 29-45.

Asongu, S. A. (2013). "How Has Mobile Phone Penetration Stimulated Financial Development in Africa", Journal of African Business, 14(1), pp. 7-18.

Asongu, S. A., (2014a). "Correcting Inflation with Financial Dynamic Fundamentals: Which Adjustments Matter in Africa?", Journal of African Business, 15(1), pp. 64-73.

Asongu, S. A., (2014b). "Knowledge Economy and Financial Sector Competition in African Countries", African Development Review, 26(2), pp. 333-346.

Asongu, S. A., (2014c). "Financial development dynamic thresholds of financial globalisation: evidence from Africa", Journal of Economic Studies, 41(2), pp. 166-195.

Asongu, S. A., (2015a). "Conditional Determinants of Mobile Phones Penetration and Mobile Banking in Sub-Saharan Africa", Journal of the Knowledge Economy,

DOI: $10.1007 \% 2 F s 13132-015-0322-\mathrm{Z}$

Asongu, S. A., (2015b). "Liberalisation and Financial Sector Competition: A Critical Contribution to the Empirics with an African Assessment", South African Journal of Economics, 83(3), pp. 425-451.

Asongu, S. A., (2015c). "Financial Sector Competition and Knowledge Economy: Evidence from SSA and MENA Countries", Journal of the Knowledge Economy, 6(4), pp. 717-748.

Asongu S. A. \& De Moor, L., (2016). "Financial globalisation dynamic thresholds for financial development: evidence from Africa", European Journal of Development Research: DOI:10.1057/ejdr.2016.10.

Asongu, S. A., \& Nwachukwu, J. C., (2016a).“The role of governance in mobile phones for inclusive human development in Sub-Saharan Africa", Technovation, 55-56

(September,October), pp. 1-13.

Asongu, S. A., \& Nwachukwu, J. C., (2016b). "The Mobile Phone in the Diffusion of Knowledge for Institutional Quality in Sub-Saharan Africa", World Development, 86(October), pp. 133-147.

Arellano, M., \& Bover, O., (1995). "Another Look at the Instrumental Variable Estimation of Error Component Model”. .Journal of Econometrics, 68(1), pp. 29-52. 
Arestis, P., Demetriades, P. O., Fattouh, B., \& Mouratidis, K., (2002). "The impact of financial liberalisation policies on financial development: evidence from developing countries", International Journal of Finance and Economics, 7(2), pp. 109-121.

Asongu, S. A., Nwachukwu, J., \& Tchamyou, S. V., (2016), "Information Asymmetry and Financial Development Dynamics in Africa", Review of Development Finance.

DOI: 10.1016/j.rdf.2016.09.001.

Ataullah, A., Cockerill, T., \& Le, H., (2004). "Financial liberalization and bank efficiency: a comparative analysis of India and Pakistan”, Applied Economics, 36(17), pp. 1915-1924.

Aryeetey, E., (2005). "Informal Finance and Private Sector Development in Africa”, Journal of Microfinance, 7(1), pp. 13-37.

Baltagi, B. H., (2008). "Forecasting with panel data", Journal of Forecasting, 27(2), pp. 153173.

Bartels, F. L., Alladina, S. N., \& Lederer, S., (2009), "Foreign Direct Investment in SubSaharan Africa: Motivating Factors and Policy Issues", Journal of African Business, 10(2), pp. 141-162.

Batuo, M. E., \& Kupukile, M., (2010), "How can economic and political liberalization improve financial development in African countries?", Journal of Financial Economic Policy, 2(1), pp. 35-59.

Bergemanny, D., Heumannz, T., \& Morris, S., (2015). "Information and Market Power", Department of Economics, Yale University, New Haven, https://economics.wustl.edu/files/economics/imce/bergemann_paper.pdf (Accessed: 16/08/2016).

Boyd, J. H., Levine, R., \& Smith, B. D., (2001), "The impact of inflation on financial sector performance", Journal of Monetary Economics, 47(2), pp. 221-248.

Brambor, T., Clark, W. M., and Golder, M., (2006). "Understanding Interaction Models: Improving Empirical Analyses”, Political Analysis, 14 (1), pp. 63-82.

Chen, C., (2009). "Bank Efficiency in Sub-Saharan African Middle-Income Countries", IMF Working Paper, No. WP/09/14, Washington.

Claus, I., \& Grimes, A., (2003). “Asymmetric Information, Financial Intermediation and the Monetary Transmission Mechanism: A Critical Review”, NZ Treasury Working Paper No. 13/019, Wellington.

Coccorese, P., (2012), "Information sharing, market competition and antitrust intervention: a lesson from the Italian insurance sector", Applied Economics, 44(3), pp. 351-359.

Coccorese, P., \& Pellecchia, A., (2010), "Testing the 'Quiet Life' Hypothesis in the Italian Banking Industry", Economic Notes by Banca dei Paschi di Siena SpA, 39(3), pp. 173-202.

Darley, W. K., (2012), "Increasing Sub-Saharan Africa's Share of Foreign Direct Investment: Public Policy Challenges, Strategies, and Implications", Journal of African Business, 13(1), 
pp. 62-69.

Demombynes, G., \& Thegeya, A. (2012). "Kenya's mobile revolution and the promise of mobile savings". World Bank Policy Research Working Paper, No. 5988, Washington.

Dewan, S., \& Ramaprasad, J., (2014). "Social media, traditional media and music sales", MIS Quarterly, 38(1), pp. 101-128.

Do, Q. T., \& Levchenko, A. A., (2004), “Trade and financial development”, World Bank Policy Research Working Paper No. 3347, Washington.

Easterly, W., (2005). "What did structural adjustment adjust? The association of policies and growth with repeated IMF and World Bank adjustment loans," Journal of Development Economics, 76(1), pp. 1-22.

Fouda, O. J. P., (2009), “The excess liquidity of banks in Franc zone: how to explain the paradox in the CEMAC", Revue Africaine de l'Integration, 3(2), pp. 1-56.

Goel, R. K., \& Hsieh, E. W. T., (2002). "Internet Growth and Economic Theory", Netnomics, 4(2), pp. 221-225.

Greenwood, J., \& Jovanovic, B., (1990), "Financial development, growth and distribution of income”, Journal of Political Economy, 98(5), pp. 1076-1107.

Hauner, D., \& Peiris, S. J., (2005). "Bank Efficiency and Competition in Low-Income Countries:The Case of Uganda", IMF Working Paper, No. WP/05/240, Washington.

Huang, Y., (2011). "Private Investment and financial development in a globalised world", Empirical Economics, 41(1), pp. 43-56.

Huang, Y., (2005), “What determines financial development?”, Bristol University, Discussion Paper No. 05/580, Bristol.

Huang, Y., \& Temple, J. R. W., (2005), "Does external trade promote financial development?" CEPR Discussion Paper No. 5150, London.

Huybens, E., \& Smith, B. D., (1999), "Inflation, financial markets and long-run real activity", Journal of Monetary Economics, 43(2), pp. 283-315.

IMF (2008, October). “International Financial Statistics Yearbook, 2008”, IMF Statistics Department.

Jaffee, D., \& Levonian, M., (2001), "Structure of banking systems in developed and transition economies", European Financial Management, 7 (2), pp. 161-181.

Kablan, S., (2009). "Mesure de l'Efficacité des Banques dans les Pays en Voie de Développement: Le Cas de l'Union Economique et Monetaire Ouest Africaine (UEMOA) ", African Development Review, 21(2), pp. 367-369.

Kablan, S., (2010). "Banking efficiency and financial development in Sub-Saharan Africa", IMF Working Paper No.10/136, Washington. 
Love, I., \& Zicchino, L., (2006). "Financial Development and Dynamic Investment Behaviour: Evidence from Panel VAR" .The Quarterly Review of Economics and Finance, 46(2), pp. 190-210.

Levine, R., (1997), "Financial development and economic growth: Views and agenda", Journal of Economic Literature, 35(2), pp. 688-726.

Meagher, K., (2013). "Unlocking the Informal Economy: A Literature Review on Linkages Between Formal and Informal Economies in the Developing Countries", WIEGO Working Paper No. 27, Cambridge.

Mensah, E., Abor, J., Aboagye, A.Q.Q., \& Adjasi, C. K. D., (2012). Enhancing the Economic Growth of Africa: Does Banking Sector Efficiency Matter?, in Kojo Menyah, Joshua Abor (ed.) Finance and Development in Africa (Research in Accounting in Emerging Economies, Volume 12 Part B) Emerald Group Publishing Limited, pp.1 - 23.

Muto, M., \& Yamano, T., (2009). "The Impact of Mobile Phone Coverage Expansion on Market Participation: Panel Data Evidence from Uganda", World Development, 37(12), pp. 1887-1896.

Osabuohien, E. S., \& Efobi, E. R., (2013). “Africa's Money in Africa”, South African Journal of Economics, 81(2), pp. 292-306.

O'Toole, C. M., (2014). "Does Financial Liberalization Improve Access to Investment Finance in Developing Countries?", Journal of Globalization and Development, 5(1), pp. 4174.

Penard, T., Poussing, N., Yebe, G. Z., \& Ella, P. N., (2012). "Comparing the Determinants of Internet and Cell Phone Use in Africa: Evidence from Gabon ", Communications \& Strategies, 86(2), pp. 65-83.

Rolfe, R. J., \& Woodward, D. P.,(2004). “Attracting foreign investment through privatization: the Zambian experience", Journal of African Business, 5(1), pp.5-27.

Roodman, D., (2009a). "A Note on the Theme of Too Many Instruments", Oxford Bulletin of Economics and Statistics, 71(1), pp. 135-158.

Roodman, D., (2009b). "How to do xtabond2: An introduction to difference and system GMM in Stata”, Stata Journal, 9(1), pp. 86-136.

Saint Paul, G., (1992), "Technological choice, financial markets and economic development", European Economic Review, 36(4), pp. 763-781.

Saxegaard, M., (2006), "Excess liquidity and effectiveness of monetary policy: evidence from sub-Saharan Africa", IMF Working Paper No. 06/115, Washington.

Tchamyou, S. V., (2016). "The role of knowledge economy in African business", Journal of the Knowledge Economy, DOI: 10.1007/s13132-016-0417-1.

Tchamyou, S. V., \& Asongu, S. A., (2017). "Information Sharing and Financial Sector Development in Africa”, Journal of African Business, 17(1), pp. 24-49. 
Tuomi, K., (2011), "The Role of the Investment Climate and Tax Incentives in the Foreign Direct Investment Decision: Evidence from South Africa", Journal of African Business, 12(1), pp. 133-147. 